\title{
Linking Perceived Quality on Attitudinal and Behavioral Loyalty: An Evidence from Indonesian App-Based Transportation
}

\section{Leonnard}

Sekolah Tinggi Manajemen, IPMI International Business School

\section{Abstract}

This study investigated app-based transportation customers' perception of quality, and its effect on satisfaction, attitudinal, and behavioral intention in the means-end theory perspective. A causal design survey was applied out of 90 customers from South Tangerang City, Province of Banten, Indonesia and the data were analyzed by

Corresponding Author: Leonnard

leonnard.ong@ipmi.ac.id

Received: 23 April 2018

Accepted: 8 May 2018

Published: 4 June 2018

Publishing services provided by Knowledge $\mathrm{E}$

(c) Leonnard. This article is distributed under the terms of the Creative Commons

Attribution License, which permits unrestricted use and redistribution provided that the original author and source are credited.

Selection and Peer-review under the responsibility of the IRCHE 2017 Conference Committee. using Partial Least Square (PLS). The research finding indicated that the relationships between perceived quality, satisfaction, attitudinal and behavioral intention were confirmed. There was a positive significant relationship of environmental quality and customer satisfaction ( $\beta=1.131 ;$ sig. $=0.000 ; C R>2.0$ ). Ambient condition contributed a higher influence on environmental quality than another indicator. Ambient condition was defined as a nonvisual factor affecting consumer perceptions of service quality. Moreover, satisfaction also had a positive relationship of attitudinal and behavioral loyalty $(\beta=0.807 ; \beta=0.743 ; \mathrm{sig}=0.000$ and $C R>2.0$ ). The indirect influence of service environmental quality on attitudinal and behavioral loyalty was also confirmed through an intermediate variable of satisfaction ( $\beta=0.912 ; \beta=0.840$; sig $=0.000$ and $C R>2.0)$. The finding is worthwhile not only for companies, but also for the welfare of drivers who mostly come from low income groups. For the company, positive attitudinal and behavioral loyalty will increase market profitability and market share in the long run. As for drivers, this condition will provide job security and welfare guarantee.

Keywords: App-based transportation, Environmental quality, Satisfaction, Attitudinal loyalty, Behavioral loyalty

\section{Introduction}

Enterprises in the field of public transportation services today become a profitable business prospects, especially in big cities in Indonesia. This is because people need 
practical and fast transportation services because of the high level of traffic congestion. App-based transportation services become effective solutions for communities, especially those who live big cities. Although currently, this app-based transportation has had a variety of services, but a motorcycle is the most widely used service option. In running its business, this app-based transportation recruited low income group and former bikers (informal transportation) as drivers. Driver recognition reveals that by joining these service companies, their revenues increase. In addition, they also get health and accident compensation, and gain access to more customers. However, the high consumer demand for this app-based transportation and the high interest of the public to join as drivers, causing competition becomes unavoidable. According to [1] and [2], this competition forces companies to improve their service quality. Improved service quality will increase customer satisfaction that will ultimately lead to consumer loyalty [3], [4].

There are growing literatures discussing perceived quality, satisfaction, and loyalty relationships [5], [6], [7], [8] however there was little evidence showed in the appbased transportation services, considering this application is still new [9], [10], [11]. Therefore, this study fills the gap. The findings will contribute to the literature by adding a new evidence of the means-end theory in the transportation services. This study is structured as follows; The next section will explain the previous theories and research that underlie this research. Based on the theoretical and empirical reviews, we built the hypotheses to be tested by using Partial Least Square (PLS) method. Furthermore, will explain the method of data collection and research results. Finally, this paper is terminated with discussion, managerial implications and study limitations.

\section{Objectives of the Study}

In this study, we investigate the interaction of perceived quality, customer satisfaction, attitudinal loyalty, and behavioral loyalty in app-based transportation in Indonesia.

\section{Literature Review}

\subsection{Perceive quality and satisfaction}

Perceived quality is the result of a thorough evaluation by consumers of post-purchase products and services [12], [13], [14]. Consumer evaluation of a product or service is determined more by how important the product or service is to the consumer. 
Therefore, perceived quality more influences consumer purchasing decisions than the real quality of products or services. This condition is explained by the mean-end theory [12].

The perceived quality has many dimensions but there is still no consensus on those dimensions. If summarized, there are four perceived quality models often used in the literature, namely the Nordic model [15], the SERVQUAL model [16], the threecomponent model [17], and the multilevel model [18]. Most of the previous literatures used the dimensions of SERVQUAL and SERVPERF [16], [19]. Yet the dimensions used in both models are deficient. For example on the dimensions of reliability and responsiveness. It remains unclear as to the limits of dimensions that are classified into reliability and responsiveness while in fact, there are many dimensions of service quality that belong to reliability and responsiveness. The same is applied to other dimensions [20]. This study adapts the perceived quality proposed by [17] which contains three dimensions, i.e. the service product (technical quality), the service delivery (functional quality), and the service environment (Figure 1).

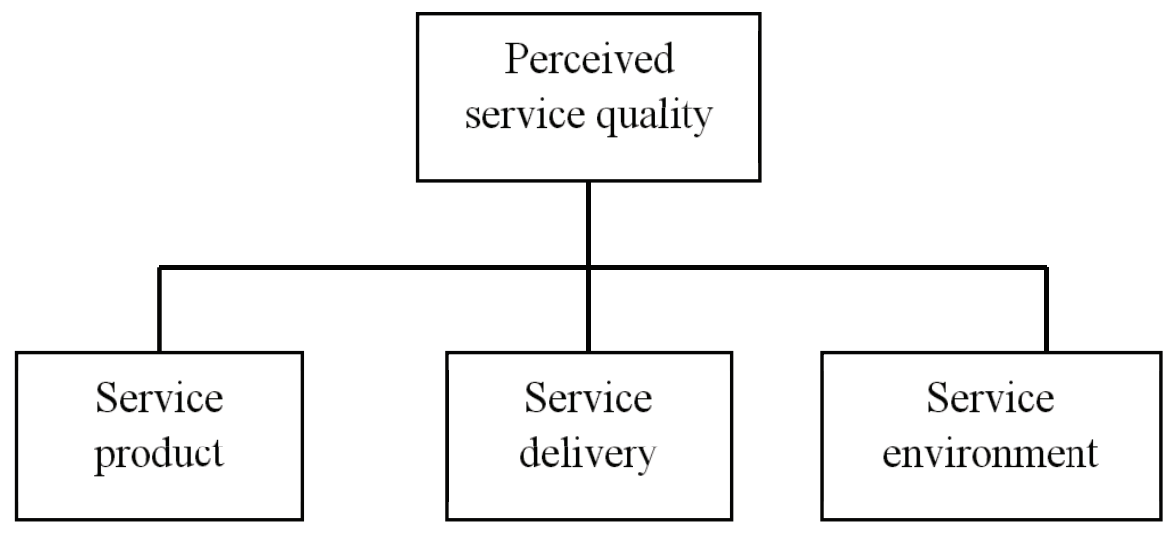

Figure 1: The three-component model. Source: [20].

\subsection{Interaction quality}

Interaction quality is the interaction that occurs between the employee and the customer during the delivery of services [21], [22]. This interaction greatly affects consumers' perceptions of those services [23]. Even [24] argue that interaction quality has more influence on perceived service quality than service outcome. The three sub dimensions of interaction quality according to [20] are attitude, behavior, and expertise. Attitude is the action and affective way that the employee does to the consumer. Behavior is the attitude shown by the employee in response to consumer attitudes. 
While expertise is the quality, knowledge, and skill employee in providing services to consumers [20].

\subsection{Environmental quality}

Environmental quality is the surrounding environment that is present when the service is provided to the consumer and will affect the consumer's perception of the service [25], [20]. The sub dimensions of environment quality consists of ambient conditions, facilities' design, and social factors. Ambient condition is nonvisual factors that affect consumer perceptions. Facilities' design is a form of architecture or layout of the surrounding environment. Finally, social factor is social factors, usually in the form of people other than consumers, which influence consumer perceptions of services [20].

\subsection{Outcome quality}

Outcome quality is the actual service received by consumers [24], [17]. Some of the previous literatures indicated that outcome quality is a major factor affecting perceived quality $[26,27]$. Outcome quality consists of waiting time, tangibles, and valence. Waiting time is the timeliness of services provided to consumers. Tangibles are physical outcomes consumed by consumers. Finally, valence is a factor of the consumer side that influences their evaluation of service quality [20]. Based on the explanation above, hypotheses are proposed as follows:

Hypothesis 1. Interaction quality positively influences customer satisfaction

Hypothesis 2. Environment quality positively influences customer satisfaction

Hypothesis 3. Outcome quality positively influences customer satisfaction

\subsection{Satisfaction, attitudinal and behavioral loyalty}

Satisfaction is the consumer's response to product evaluation after consuming the product or service. The response is in accordance with what is expected or otherwise [16]. Satisfied responses must meet the instrumental and expressive criteria. Instrumental criteria are related to physical product performance whereas expressive criteria relate to product performance emotionally [28]. A satisfied consumer will result in attitudinal and behavioral loyalty [3], [4]. Attitudinal loyalty is a tendency or a consumer's preference for a particular product or service than a competitor's product or service. Practically, attitudinal loyalty does not always result in buyback behavior by 
consumers, but this behavior gives a positive impression of the product or service [6], [29], [30]. The two dimensions of attitudinal loyalty are emotional commitment and switching cost [31]. While behavioral loyalty is the loyalty of consumers who generate purchases. Behavioral forms of loyalty can be in the form of repurchase intention and word-of-mouth (WOM) [32], [33], [31]. There are 2 indicators used to measure customer satisfaction that is the expectation and the performance. The expectation is a consumer's expectation of the products and services they consume. While the performance is the actual service that provides satisfaction for consumers [34]. Based on the explanation above, hypotheses are proposed as follows:

Hypothesis 4. Satisfaction positively influences attitudinal loyalty

Hypothesis 5. Satisfaction positively influences behavioralloyalty

\section{Conceptual Model}

Based on the literature review and the result of previous empirical studies, we propose the relationship analysis of perceived service quality, satisfaction on attitudinal and behavioral loyalty. The classification of intention in this study is intended to analyze the differences in the influence of control variables on both types of customer intention. The conceptual relationship between the analyzed variables is shown in Figure 2 below.

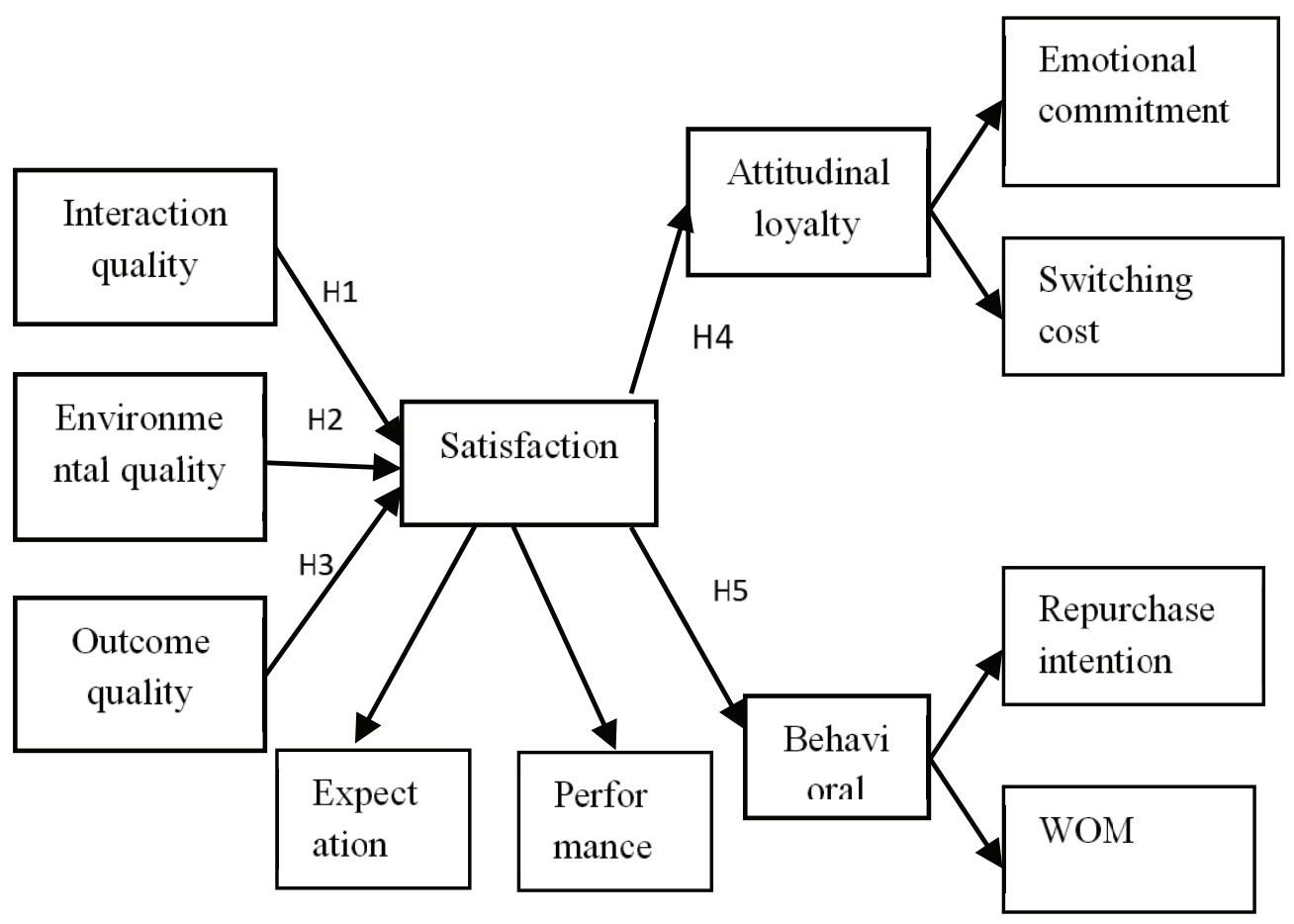

Figure 2: Conceptual model. 


\section{Methods}

\subsection{Measurement development}

The measurement of development constructs in this study was adapted from the literature. Attitudinal loyalty is measured by indicators of repurchase intention and WOM while the behavioral intention is measured by indicators emotional commitment and switching cost [31]. The dimensions used in satisfaction were are adopted from [34]. Finally, perceived quality is measured by indicators adopted from [16].

\subsection{Sample and data collection}

The data were collected from 90 app-based transportation customers in South Tangerang City, Banten Province, Indonesia by using accidental sampling with adult age criteria from the age range 18 years to 60 years and also have used app-based transportation services more than 2 times. The measurements in this questionnaire use the Likert scale divided into 4 points of the scale with the same interval, i.e. strongly agree (4), agree (3), disagree (2), and strongly disagree (1). The Partial Least Square (PLS) was employed out to analyze the data.

\section{Results}

\subsection{Evaluation of measurement model}

The evaluation of the structural model indicates that the model has reached the convergence validity and discriminant validity. The first evaluation of convergent validity indicates that each dimension used as a manifest variable has been reliable and has good validities noticed from standardize loadings of all dimensions $>.70$. The critical ratio value $>.70$ indicates that the overall loading factors are significant. A second evaluation of convergent validity indicates that the six latent variables have a high reliability as a tool where the value of D.G rho PCA (composite reliability) >.70. The AVE value of all latent variables $>.50$ indicates the high variability described by the dimensions. Satisfaction has the highest AVE value (.951), followed by the latent interaction quality variable (.834), attitudinal loyalty (.833), behavioral loyalty (.831), and outcome quality (.723). Environmental quality has the lowest AVE score (.693) (Table 1). 
TABLE 1: Convergent Validity and Discriminant Validity.

\begin{tabular}{|c|c|c|c|c|c|c|c|}
\hline $\begin{array}{l}\text { Latent } \\
\text { variables }\end{array}$ & Dimensions & $\begin{array}{l}\text { Std. } \\
\text { loadings }\end{array}$ & Std. error & $\begin{array}{l}\text { Critical } \\
\text { ratio (CR) }\end{array}$ & $\begin{array}{l}\text { Cronbach's } \\
\text { alpha }\end{array}$ & $\begin{array}{l}\text { D.G. rho } \\
\text { (PCA) }\end{array}$ & AVE \\
\hline \multirow{3}{*}{$\begin{array}{l}\text { Interaction } \\
\text { quality }\end{array}$} & Attitude & .925 & .017 & 55.274 & .897 & .936 & .834 \\
\hline & Behavior & .844 & .037 & 22.788 & & & \\
\hline & Expertise & .968 & .010 & 92.979 & & & \\
\hline \multirow[t]{2}{*}{$\begin{array}{l}\text { Environmental } \\
\text { quality }\end{array}$} & $\begin{array}{l}\text { Ambient } \\
\text { conditions }\end{array}$ & .943 & .015 & 62.574 & .600 & .834 & .693 \\
\hline & Design & .705 & .099 & 7.150 & & & \\
\hline \multirow{2}{*}{$\begin{array}{l}\text { Outcome } \\
\text { quality }\end{array}$} & Waiting time & .920 & .019 & 48.343 & .635 & .846 & .723 \\
\hline & Tangibles & .774 & .086 & 8.995 & & & \\
\hline \multirow[t]{2}{*}{ Satisfaction } & Expectation & .972 & .010 & 96.534 & .948 & .975 & .951 \\
\hline & Performance & .978 & .006 & 154.801 & & & \\
\hline \multirow[t]{2}{*}{$\begin{array}{l}\text { Attitudinal } \\
\text { loyalty }\end{array}$} & $\begin{array}{l}\text { Emotional } \\
\text { commitment }\end{array}$ & .919 & .012 & 78.516 & .780 & .915 & .833 \\
\hline & $\begin{array}{l}\text { Switching } \\
\text { cost }\end{array}$ & .906 & .038 & 23.940 & & & \\
\hline \multirow[t]{2}{*}{$\begin{array}{l}\text { Behavioral } \\
\text { loyalty }\end{array}$} & $\begin{array}{c}\text { Repurchase } \\
\text { intention }\end{array}$ & .930 & .012 & 79.926 & .777 & .915 & .831 \\
\hline & $\begin{array}{l}\text { Word of } \\
\text { mouth } \\
\text { (WOM) }\end{array}$ & .892 & .058 & 15.404 & & & \\
\hline
\end{tabular}

Furthermore, discriminant validity evaluation through the evaluation of crossloadings variables indicates that the value of each loading factor on attitude dimension (.925), behavior (.844), and expertise (.968) has a higher correlation to variable interaction quality than the other five latent variables. This evaluation implies that interaction quality can be explained by the three dimensions of attitude, behavior, and expertise well. In other words, discriminant validity has been achieved. The same case is applied in the dimensions of waiting time, expectation, performance, switching cost, and WOM. However, tangible dimensions do not have a moderate correlation to outcome quality (.774). Similarly, the same case is obtained in emotional commitment (.919) and repurchase intention (.930). However, these three dimensions are still considered to have a high correlation $(>.70)$ so that it can still be considered that those three dimensions are able to explain their latent variables (Table 2 ).

\subsection{Evaluation of structural model}

The result of hypothesis testing simultaneously indicates that the model development of perceived service quality on satisfaction is valid. There is at least one influential 
TABLE 2: Cross-Loadings Results.

\begin{tabular}{|c|c|c|c|c|c|c|}
\hline & $\begin{array}{c}\text { Interaction } \\
\text { quality }\end{array}$ & $\begin{array}{c}\text { Environmental } \\
\text { quality }\end{array}$ & $\begin{array}{l}\text { Outcome } \\
\text { quality }\end{array}$ & Satisfaction & $\begin{array}{l}\text { Attitudinal } \\
\text { loyalty }\end{array}$ & $\begin{array}{c}\text { Behavioral } \\
\text { loyalty }\end{array}$ \\
\hline Attitude & .925 & .872 & .898 & .762 & .862 & .856 \\
\hline Behavior & .844 & .698 & .686 & .627 & .733 & .668 \\
\hline Expertise & .968 & .906 & .906 & .766 & .939 & .921 \\
\hline $\begin{array}{l}\text { Ambient } \\
\text { conditions }\end{array}$ & .796 & .943 & .895 & .980 & .808 & .751 \\
\hline Design & .768 & .705 & .647 & .438 & .795 & .799 \\
\hline Waiting time & .746 & .854 & .920 & .892 & .745 & .741 \\
\hline Tangibles & .863 & .747 & .774 & .523 & .886 & .873 \\
\hline Expectation & .778 & .889 & .833 & .972 & .780 & .710 \\
\hline Performance & .764 & .924 & .860 & .978 & .794 & .737 \\
\hline $\begin{array}{l}\text { Emotional } \\
\text { commitment }\end{array}$ & .903 & .976 & .970 & .959 & .919 & .879 \\
\hline $\begin{array}{l}\text { Switching } \\
\text { cost }\end{array}$ & .785 & .707 & .708 & .499 & .906 & .843 \\
\hline $\begin{array}{l}\text { Repurchase } \\
\text { intention }\end{array}$ & .938 & .983 & .964 & .903 & .975 & .930 \\
\hline $\begin{array}{l}\text { Word of } \\
\text { mouth } \\
\text { (WOM) }\end{array}$ & .672 & .590 & .678 & .402 & .722 & .892 \\
\hline
\end{tabular}

latent variable in the model $(F=218.769$; sig. $=.000)$. Individual test on satisfaction variable indicates that there is one variable manifest that has significant effect that is environmental quality (sig. $=.000$ and $C R>2.0$ ). Environmental quality gives an effect of 1,131 on consumer satisfaction of applied mobile technology. Therefore the resulting structural equation model is satisfaction $=-.353 *$ interaction quality $+1.131^{*}$ environmental quality $+.128^{*}$ outcome quality, with $R^{2}$ value of.884 (model 1 ). The results of further tests indicate that there is a positive significant effect of satisfaction on attitudinal and behavioral loyalty ( $\mathrm{sig}=.000$ and $C R>2.0$ ). The magnitude of the effect of satisfaction on attitudinal loyalty $(.807)$ is greater than on the behavioral loyalty (.743). Therefore the resulting structural equation model is attitudinal loyalty $=.807$ * satisfaction $\left(R^{2}=.652\right)($ model 2$)$ and attitudinal loyalty $=.743$ * satisfaction $\left(R^{2}=.552\right)$ (model 3) (Table 3).

The result of evaluation on direct and indirect influence between latent variables indicates that indirect effect of environmental quality toward attitudinal loyalty is equal to.912 and to behavioral loyalty of.840. This effect is generated through the influence of satisfaction as an intermediate variable. The amount of indirect influence is obtained when consumers are satisfied with what they expect from the ambient conditions and the design of applied mobile technology. The magnitude of this influence is greater 
TABle 3: Path Coefficient Results.

\begin{tabular}{|c|c|c|c|c|}
\hline Latent variables & Coeff. & Std.error & t-value & Critical ratio \\
\hline $\begin{array}{l}\text { Interaction quality } \\
\text { Satisfaction }\end{array}$ & -.353 & .097 & -3.653 & -2.995 \\
\hline $\begin{array}{l}\text { Environmental } \\
\text { quality } \\
\text { Satisfactionon }\end{array}$ & 1.131 & .115 & 9.814 & 6.692 \\
\hline $\begin{array}{l}\text { Outcome quality } \\
\text { Satisfaction }\end{array}$ & .128 & .120 & 1.071 & .731 \\
\hline $\begin{array}{l}\text { Satisfaction } \\
\text { Attitudinal loyalty }\end{array}$ & .807 & .063 & 12.835 & 30.555 \\
\hline $\begin{array}{l}\text { Satisfaction } \\
\text { Behavioral loyalty }\end{array}$ & .743 & .071 & 10.405 & 23.771 \\
\hline
\end{tabular}

than the magnitude of the effect of satisfaction on attitudinal and behavioral loyalty (Table 4).

TABLE 4: Direct and Indirect Effects.

\begin{tabular}{|c|c|c|c|c|c|c|c|c|c|c|c|c|}
\hline & \multicolumn{3}{|c|}{ Interaction quality (IQ) } & \multicolumn{3}{|c|}{ Environmental quality (EQ) } & \multicolumn{3}{|c|}{ Outcome quality (OQ) } & \multicolumn{3}{|c|}{ Satisfaction (S) } \\
\hline & $\mathrm{D}$ & I & $\mathrm{T}$ & $\mathrm{D}$ & 1 & $\mathrm{~T}$ & $\mathrm{D}$ & 1 & $\mathrm{~T}$ & $\mathrm{D}$ & I & $\mathrm{T}$ \\
\hline \multicolumn{13}{|l|}{ IQ } \\
\hline EQ & .000 & .000 & .000 & & & & & & & & & \\
\hline $\mathrm{OQ}$ & .000 & .000 & .000 & .000 & .000 & .000 & & & & & & \\
\hline$S$ & -.353 & .000 & -.353 & 1.131 & .000 & 1.131 & .128 & .000 & .128 & & & \\
\hline$A L$ & .000 & -.284 & -.284 & .000 & .912 & .912 & .000 & .103 & .103 & .807 & .000 & .807 \\
\hline $\mathrm{BL}$ & .000 & -.262 & -.262 & .000 & .840 & .000 & .000 & .095 & .095 & .743 & .000 & .743 \\
\hline \multicolumn{13}{|c|}{$\mathrm{AL}=$ Attitudinal Loyalty } \\
\hline \multicolumn{13}{|c|}{ BL = Behavioral Loyalty } \\
\hline
\end{tabular}

The evaluation of effect size $\mathrm{f}^{2}$, goodness of fit (GoF), and Stone-Geisser's $\mathrm{Q}^{2}$ indicates that the effect effect size $\mathrm{f}^{2}$ for model 1 of variable interaction quality is.155, environmental quality is 1.120, and outcome quality is.013. The largest effect is only provided by the environmental quality variable, while the interaction and outcome quality give very little effect. While on model 2 and 3 , the effect size $f^{2}$ of satisfaction is 1,872 and 1,230. Both have effects more than 1,000. Evaluation of GoF values indicates that the model has a high ability to explain the data (GoF $=.752$ ). Finally, an evaluation of Stone-Geisser's Q2 values indicates that the exogenous latent variable used has good ability to explain endogenous variables (redundancies $>.000$ ). The research structural model is denoted in Figure 3. 


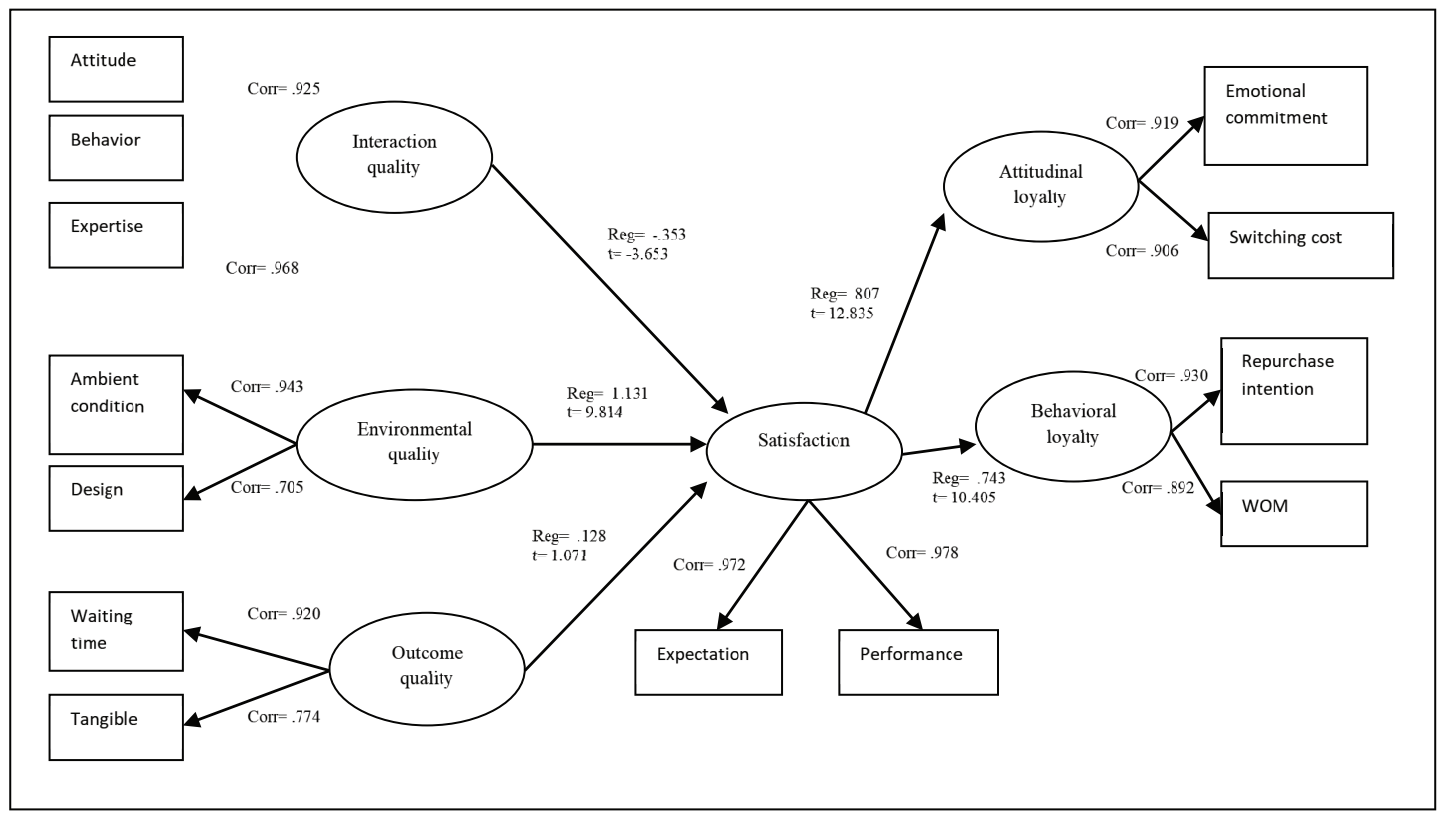

Figure 3: Research Output Diagram.

\section{Discussions}

The findings of this study indicate that a significant factor affects consumer satisfaction app-based transportation in Indonesia is service environment quality. This fact is consistent with [25], [20], [35], [36]. Ambient conditions signify a higher correlation to environmental quality than design. Since the ambient condition in this study is defined as a nonvisual factor affecting consumer perceptions of service quality, the company needs to focus on improving non-visual aspects such as neatness, driver's health, comfort and cleanliness of the facilities.

Satisfaction proved to significantly affects attitudinal and behavioral loyalty with greater effect on attitudinal than behavioral loyalty. This finding is consistent with [3] and [4]. The effect of satisfaction on attitudinal loyalty is greater than behavioral loyalty. Attitudinal loyalty consists of emotional commitment and switching costs. Emotional commitment has a higher correlation to attitudinal loyalty than switching costs. This is consistent with [31]. Emotional commitment is the factors associated with consumer emotions to services. This emotional commitment leads to customer loyalty [31]. While the switching cost is the cost that must be issued by consumers when they switch to competitor's services. The higher the cost to be sacrificed, the higher the consumer barrier to disloyal to the company's services. This switching cost leads to customer loyalty [3], [37]. Behavioral loyalty consists of repurchase intention and WOM. Repurchase intention has a higher correlation to behavioral loyalty than 
WOM. This is consistent with [31]. By definition, repurchase intention is a consumer intention to use future services while WOM is a consumer intention to spread positive impressions about services [32], [33], [31]. These two dimensions lead to customer loyalty.

Environment quality has a high total effect on attitudinal and behavioral loyalty. This effect is generated after consumers are satisfied with the services of app-based transportation. In other words, ambient condition and facilities' design given has been in accordance with the expected consumer. The higher the total effect on attitudinal loyalty indicates that the effect of neatness, driver health and comfort and cleanliness of the facilities affect the emotional and consumer feelings and create barriers to switch to competitor's services. The indirect effect of ambient conditions on behavioral loyalty is demonstrated through the effect of neatness, driver health, comfort and facility hygiene over the recurrent use of services in the future and a desire to spread a positive impression of service. Neat and healthy drivers will influence consumers' desire to spread this impression to the public. With the presence of social media, this positive impression becomes very easy to disseminate (viral). The same case is applied to the neatness and the health of the driver. In addition, it also affects consumers' desire to use future services.

Facilities' design in this study consisted of SNI standard helmets, diverse services, and ease of transactions. Consumer satisfaction with those factors will lead to attitudinal and behavioral loyalty. Satisfaction with the availability of helmets of SNI standard provides consumer security while using the services of app-based transportation. Different services and ease of transactions that include cash and non-cash transactions give effect to emotion and emotional commitment and switching costs. The diverse services offered by app-based transportation will create a barrier for consumers to switch services because competitors do not all provide the same services. This condition will indirectly create the switching cost. Similarly, the presence of non-cash payments on app-based transportation causes the cost incurred by consumers to be cheaper than switching to competitor services using cash transactions. This condition will create a barrier for consumers to be loyal to the service.

\subsection{Managerial implications}

These findings lead to several managerial implications. It will help app-based transportation companies in determining what factors affect their customer satisfaction and ultimately leads to customer loyalty. Keeping their loyal customers is a challenge 
since there are many emerging service competitors with diverse service offerings and competitive pricing. In addition, public interest from low income groups to register as drivers causes a high competition among drivers. If it is not accompanied by an increase in the number of consumers, then this will cause welfare problems. Based on empirical findings, the factor that affects consumer satisfaction is the environment quality. Interaction and outcome quality are not proven to affect consumer satisfaction. The company's attention to neatness, driver's health, comfort and cleanliness of facilities, the availability of SNI standard helmets, diverse services, and ease of transactions are essential in creating customer satisfaction that will ultimately lead to customer loyalty. In addition to giving attention to the application (variety of services and ease of transactions), the company also needs to pay attention to the non-visual aspects of drivers who directly interact with consumers. In addition, the company can add attributes associated with emotional consumers to increase consumer satisfaction.

\section{Conclusion}

We conlude that there are significant relationships between perceived quality, satisfaction, attitudinal and behavioral intention. However, this study has several limitations. First, this study uses only 90 samples that use the services of app-based transportation more than twice. The selected sample is 18 to 60 years old. This condition causes the results obtained cannot be generalized to all consumers of app-based transportation. In addition, the sample selection from one location is not enough to represent consumers from all big cities in Indonesia since consumer behavior towards app-based transportation may be different in each of these big cities. Subsequent research is suggested to consider aspects of location, age, occupation and other control variables in the analysis that may influence consumer perceptions of service quality, satisfaction and loyalty. Second, although the analysis of this research is conducted within the framework of mean-ends theory, this study does not include perceived price and perceived value variables in the analysis. The inclusion of these two variables in the analysis in the future will be suggested..

\section{References}

[1] Matsa, D. A. (2011). Competition and product quality in supermarket industry. The Quarterly Journal of Economics 26(3), 1539-1591. 
[2] Rupp, N. G., Owens, D. H. \& Plumly, L. W. (2006). Does competition influence airline on-time performance? in D. Lee (ed.), Advances in Airline Economics, 1 (2006) Elsevier.

[3] Shoemaker, S., Lewis, R.C. (1999). Customer loyalty: The future of hospitality marketing. International Journal of Hospitality Management 18(4), 345-370.

[4] Gumussoy, C.A., \& Koseoglu, B. (2016). The effects of service quality, perceived value and price fairness on hotel customers' satisfaction and loyalty. Journal of Economics, Business and Management 4(9), 523-527.

[5] Leonnard, L., Daryanto, H. K., Sukandar, D., \& Yusuf, E. Z. (2013). The loyalty model of private university student, study case: stikom london school of public relation. International Journal of Information Technology and Business Management, 20(1).

[6] Leonnard, L., Daryanto, H. K., Sukandar, D., \& Yusuf, E. Z. (2015). The Loyalty Model of Private University Student (pp 55-68). International Research Journal of Business Studies, 7(1).

[7] Leonnard, L. (2017). Measuring grocery stores service quality in indonesia: a retail service quality scale approach. Studies and Scientific Researches. Economics Edition, (26).

[8] Leonnard. (2018). The Performance of SERVQUAL to Measure Service Quality in Private University. Journal on Efficiency and Responsibility in Education and Science, 11(1): 16-21.

[9] Kang, S.S., Nobuyuki, O., \& Herbert, D. (2004). Service quality and its effects on customer satisfaction and customer behavioral intention: Hotel and ryokan guests in Japan. Asia Pacific Journal Tour Research 9(2), 189-203.

[10] Kumar V., Shah D., \& Venkatesan R. (2006). Managing retailer profitability-one customer at a time. Journal of Retailing 82(4), 277-294.

[11] Kasiri, L. A., Cheng, K. T. G., Sambasivan, M., \& Md Sidin, S. (2017). Integration of standardization and customization impact on service quality, customer satisfaction, and loyalty. Journal of Retailing and Consumer Services 35(2017), 91-97.

[12] Zeithaml, Valarie A. (1988). Consumer perceptions of price, quality, and value: A means-end model and synthesis of evidence.journal of Marketing 52 (1988), 2-22.

[13] Meshack, H. E., \& Data, S.K. (2015). Assessing the effects of service quality and customer satisfaction a study hotels in Arusha as a tourism destination. Zenith International Journal of Multidisciplinary Research 5(6),168-181.

[14] Liu, C. S., \& Lee, T. (2016). Service quality and price perception of service: Influence on word-of-mouth and revisit intention. Journal of Air Transport Management 52 (2016), 42-54. 
[15] Grönroos, C. A. (1984). Service quality model and its marketing implications. European Journal of Marketing 18(4), 36-44.

[16] Parasuraman, A., Zeithaml, V.A. and Berry, L.L. (1988). SERVQUAL: A multiple-item scale for measuring consumer perceptions of service quality.Journal of Retailing, 12-40.

[17] Rust, R. T. \& Oliver, R. L. (1994). Service quality: Insights and managerial implications from the frontier in service quality: New directions in theory and practice. Roland T. Rust and Richard L. Oliver, eds. Thousand Oaks, CA: Sage Publications, 1-19.

[18] Dabholkar, P.A., Thorpe, D.L., \& Rentz, J.O. (1996). A measure of service quality for retail stores: Scale development and validation. Journal of the Academy Marketing Science $24(3), 3-16$.

[19] Cronin, J.J., \& Taylor, S. A. (1992). Measuring service quality: A reexamination and extension. Journal of Marketing 56(1992), 55-68.

[20] Brady, M. K., \& Cronin, J. J. (2001). Some new thoughts on conceptualizing perceived service quality: A hierarchical approach. The Journal of Marketing 65(3), 34-49.

[21] Bitner, M.J., Booms, B.H., \& Mohr, L.A. (1994). Critical service encounters: The employee's view. Journal of Marketing, 58(1994), 95-106.

[22] Hartline, M. D. \& Ferrell, O.C. (1996). The management of customer contact service employees: An empirical investigation. Journal of Marketing, 69 (1996), 52-70.

[23] Czepiel, J.A. (1990). Service encounters and service relationships. Journal of Business Research, 20(1), 13-21.

[24] Surprenant, C. F. \& Solomon, M. R. (1987). Predictability and personalization in the service encounter. Journal of Marketing, 51(1987), 86-96.

[25] Bitner, M.J. (1992). Servicescapes: The impact of physical surroundings on customers and employees. Journal of Marketing, 56(1992), 57-71.

[26] Mc Alexander, J. H., Kaldenberg, D. O., \& Koenig, H. F. (1994). Service quality measurement. Journal of Health Care Marketing, 3(1994), 34-40.

[27] de Ruyter, K., \& Wetzels, M. (1998). On the complex nature of patient evaluations of general practice service. Journal of Economic Psychology, 19(5), 565-90.

[28] Swan, J.E. and Combs, L.J. (1976). Product performance and consumer satisfaction: A new concept. Journal of Marketing, 40 (1976), 25-33.

[29] Jones, T. \& Taylor, S. (2007). The conceptual domain of service loyalty: How many dimensions? Journal of Service Marketing 26(1), 36-51. 
[30] Shih-I, C. 2011. Comparisons of completing models between attitudinal loyalty and behavioral loyalty. International Journal of Business and Social Science 2 (10), 149166.

[31] Tanford, S. (2013). The impact of tier level on attitudinal and behavioral loyalty of hotel reward program members. International Journal of Hospitality Management 34(2013), 285-294.

[32] Hansen, J.D., Deitz, G.D., Morgan, R.M. (2010). Taxonomy of service-based loyalty program members. Journal of Services Marketing 24(4), 271-282.

[33] Gracia, E., Bakker, A.B., Grau, R.M. (2011). Positive emotions: The connection between customer quality evaluations and loyalty. Cornell Hospitality Quarterly 52 (4), 458-465.

[34] Kotler, P. \& Keller, K. L. (2009). Marketing management (13th end). New Jersey: Pearson Education Inc, Upper Saddle River.

[35] Zalejska-Jonsson, A., \& Wilhelmsson, M. (2013). Impact of perceived indoor environment quality on overall satisfaction in Swedish dwellings. Building and Environment 63(2013), 134-144.

[36] Han, H., \& Hyun, S.S. (2017). Impact of hotel-restaurant image and quality of physical-environment, service, and food on satisfaction and intention. International Journal of Hospitality Management 63(2017), 82-92.

[37] Mattila, A.S. (2006). How affective commitment boosts guest loyalty (and promotes frequent guest programs). Cornell Hotel and Restaurant Administration Quarterly $47(2), 174-181$. 